Yeni Kurulan Kardiyoloji Merkezinin Kardiyak Manyetik Rezonans Görüntüleme Deneyimi

\title{
Cardiac Magnetic Resonance Imaging Experience of a Newly Established
}

\section{Cardiology Center}

Kıvanç Yalın'1, Tümer Erdem Güler², Şükrü Şanlı ${ }^{3}$

1 Uşak Üniversitesi Tıp Fakültesi, Kardiyoloji Anabilim Dalı, Uşak, Türkiye

2 Sağlık Bilimleri Üniversitesi, Derince Eğitim ve Araştırma Hastanesi, Kardiyoloji Kliniği, Kocaeli, Türkiye

3 Bayrampaşa Kolan Hastanesi, Radyoloji Kliniği, İstanbul, Türkiye

\section{$\ddot{O} Z$}

GİRIŞ ve AMAÇ: Kardiyak manyetik rezonans görüntüleme (KMRG) miyokardiyal hastalıkların değerlendirmesinde giderek artan oranda kullanılmaktadır.

YÖNTEM ve GEREÇLER: Çalışmamızda kliniğimizde 1 yıl içerisinde yapılan KMRG incelemelerinin ESC k1lavuzlarına uygunluğu, klinik yaklaşımı değiştirmedeki yeri araştırılmıştır.

BULGULAR: Çalışmaya 30 hasta dahil edilmiş olup, yapılan incelemeler ESC kılavuzlarına uygun olup, 7 hastada (\%23) klinik yaklaşımı değiştirmiştir.

TARTIŞMA ve SONUÇ: Çalışmamız bulguları KMRG' nin daha yaygın kullanılması gerektiğini düşüncesini desteklemektedir.

Anahtar Kelimeler: Kardiyak manyetik rezonans görüntüleme, endikasyon, kılavuz

\section{ABSTRACT}

INTRODUCTION: Cardiac magnetic resonance imaging (CMRI) is currently increasingly been used for evaluation of myocardial diseases.

METHODS: In this work, we investigated the accuracy of last one year CMRI to ESC guidelines and the role of changing the clinical approach.

RESULTS: Thirty patients enrolled, imaging was found to be accurrent to ESC guidelines, CMRI changed clinical approach in $7(23 \%)$ of the patients.

DISCUSSION and CONCLUSION: Our data suggest the idea of wider use of CMRI.

Keywords: Cardiac magnetic resonance imaging, indication, guideline 


\section{INTRODUCTION}

Cardiac magnetic resonance imaging (CMRI) is becoming increasingly popular in clinical cardiology. The most frequent indication is evaluation of ischemic or inflammatory cardiomyopathies. However, less commonly it is used for congenital heart diseases and infiltrative diseases, such as amyloidosis (1-2).

CMRI demonstrates myocardial pathologies very well with its myocardial resolution near perfection, behind anatomical data (3). Modality can able to discriminate myocardial edema and irreversible myocardial fibrosis, and it can be diagnostic by showing the anatomical localization and specific involvement in the myocardium. Another advantage of the technique is that data can be obtained without exposure to radiation during processing.

Despite its advantages, there are some limiting factors of its use in our country. These include; lack of knowledge and experience for reporting, longer duration of imaging compared to other MRI techniques, and the need for special software to perform specific measurements. Another limitation is that in patients with some type of metallic heart valves and implanted metallic prostheses CMRI cannot be performed. In this study, we present the CMRI experience of a newly established cardiology center.

\section{METHODS}

Thirty patients underwent CMRI study between March 2016 and March 2017 in our institution. The analysis was performed retrospectively. Compliance with the ESC guidelineswas assessed as to whether the CMRI changed the clinical management of patient. CMRI was performed using the method described previously with 1.5 Tesla Siemens Essenza (Forchheim, Germany) $(4,5)$. CMR images were evaluated and reported by ŞŞ ( 3 years experience in CMRI).

CMRI recommendation on ESC guidelines for compliance of the present CMRI in patients with the guideline has been screened. If the same recommendation is included in more than one guideline, the most up-to-date guideline had been taken into account. We reported there was a change in the clinical management of the patient after
CMRI if the patient underwent additional interventional therapy or any change of standard care as a result of CMRI.

\section{RESULTS}

This study was included 30 (24 male, 6 female) patients. Mean age was $49.7+/-13.8$ years old. Nine of the patients had severe left ventricular systolic dysfunction (left ventricular ejection fraction less than $30 \%$ ) and normal coronary arteries. CMRI was performed to determine the prognosis of dilated cardiomyopathy. In 2 of these patients had patchy late contrast enhancement was seen. As it is well known that in patients with nonischemic dilated cardiomyopathy, late contrast enhancement was related to all cause mortality, sudden cardiac death and hospitalizations due to heart failure exacerbation; an ICD was implanted to patients who have late enhancement. Furthermore, in one of nine patients typical pattern for myocardial noncompaction was detected, and ICD implantation and anticoagulation were recommended to this patient. According to chronic heart failure guideline, in the presence of inadequate echogenicity or failure of 2-D echocardiography CMRI is recommended (Class 1 indication). In our study 9 CMRI study for heart failure patients were consistent to guideline, in $3(33 \%)$ of these management was changed.

In 3 cases, CMRI was performed due to suspicion of pericardial pathology. Two of these patients had suspected pericardial cyst, one had echocardiographic and hemodynamic findings of pericardial constriction and CMRI was performed to evaluate pericardial inflammation. Pericardial cyst was diagnosed in one of these patients and localized pericardial fluid was detected in other patient. Septal bounce movement was observed in the patient with pericardial constriction physiology and the pericardium was found to be thickened. Late contrast enhanced images that demonstrated extensive contrast enhancement of the pericardium were considered as active inflammation. Antiinflammatory treatment was administered and after 3 months follow-up, the patient was symptom free and had no signs of pericardial constriction. The imaging studies in our study for pericardial diseases were consistent with the guidelines $(6,7)$. Identification of a reversible cause of pericardial 
constriction by CMRI was changed management of the patient.

In the presence of ARVC suspicion, evaluation of right ventricular size, structure and function can be performed by CMRI and guideline recommends CMRI fort his indication (8).

In our study, CMRI was performed in 7 patients because of frequent right ventricular premature beats or right ventricular tachycardias. Transthoracic echocardiography supported the diagnosis of AVRC in 4 patients, but could not clarified in any patients. CMRI diagnosis was confirmed in 1 out of 7 (14\%) patients (Figure 1). ICD implantation has been performed to this patient, and the clinical management was changed. Chest pain patients with positive troponin level and normal coronaries underwent CMRI and imaging was reported as in normal ranges. CMRI could not identify cause of positive troponin level. Acute coronary syndrome without persistent ST segment elevation guideline8 recommends CMRI for diagnosis of myocarditis and Tako-tsubo cardiomyopathy, in our study indication for CMRI was consistent with guideline.

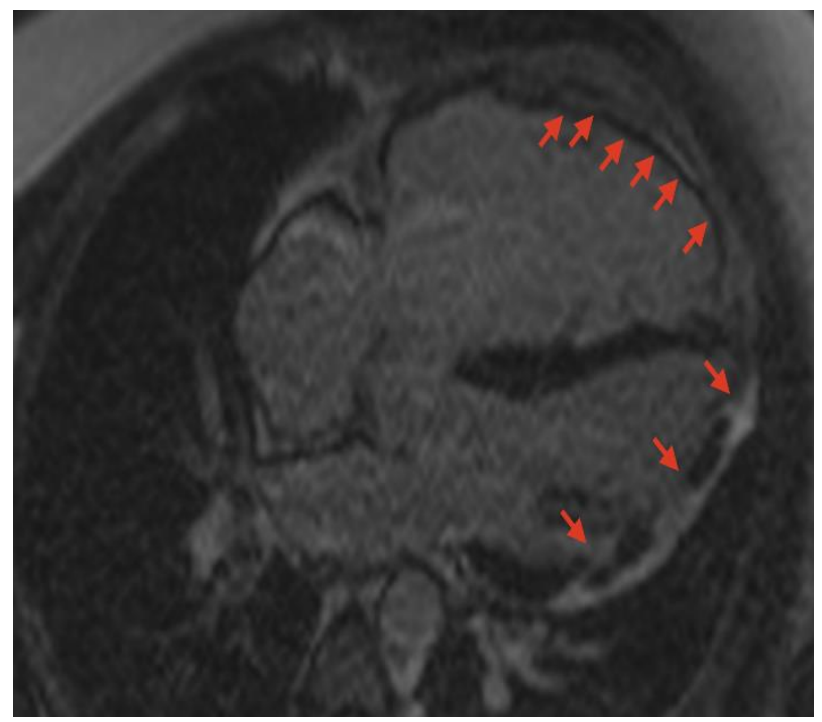

Figure 1. CMRI of an ARVC patient. Right ventricular dilatation and contrast enhancement in right ventricle and epicardial aspect of lateral wall of left ventricle.

Five patients underwent CMRI to evaluate myocardial viability. In patients with previous myocardial infarction, CMRI showed late contrast enhancement in regions with segmental wall motion abnormality. In one patient with recent myocardial infarction, black zones within scar region indicating microvascular obstruction was observed. Clinical management was not changed in this patient with microvascular obstruction. Despite we did not perform stress perfusion imaging for ischemia evaluation, extensive transmural scar area $(32 \%$ of left ventricle) in one patient with previous anterior myocardial infarction, revascularization was abandoned. According to guideline, CMRI is indicated if echocardiographic evaluation of myocardial scar is inadequate (9). Viability assessment in our study is consistent to guideline. Also, in one patient revascularization was abandoned, and clinical management was changed.

After revascularization of right coronary artery for inferior myocardial infarction, patient had hemodynamic instability and pulmonary edema on third day. Echocardiography was not diagnostic due to suboptimal acoustic window. CMRI identified post-myocardial infarction ventricular septal rupture (Figure 2), and the patient underwent urgent surgery. CMRI changed management of this patient.

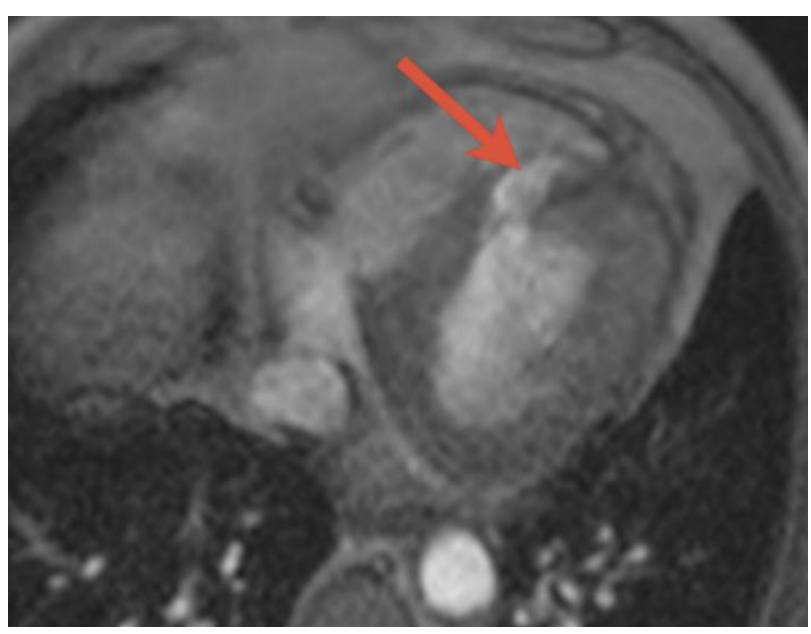

Figure 2. Post-myocardial infarction ventricular septal rupture.

In 3 patients, CMRI was performed to evaluate thoracic aortic aneurysm, surgery needed for none of these patients. Guideline10 recommends CMRI for confirmation of aortic diameter for patients who have inadequate echocardiographic examination and whose aortic diameter is more than $50 \mathrm{~mm}$ or enlarging more than $3 \mathrm{~mm}$ per year. CMRI indication in our study is consistent with current guidelines, and did not change management. One patient had suspicious vegetation on tricuspid valve, CMRI was performed to characterize lesion. CMRI 
showed papillary fibroelastoma, and the patients is currently under follow-up.

\section{DISCUSSION}

In our study, short-term CMRI indications and experience of a newly established cardiology center were evaluated. In all patients, indication for CMRI was consistent with ESC guidelines. In 7 (23\%) patients CMRI changed clinical management of the patient.

When guidelines are evaluated, it can be seen that most of the proposals for coronary artery disease focus on ischemia detection by the imaging technique. Nuclear cardiology and stress echocardiography are suggested, with no specific recommendations for CMRI. In addition, the guidelines are conservative for CMRI in evaluating viability, on the other hand CMRI is able to detect wall motion abnormalities, perfusion and scar tissue well because of its myocardial resolution close to perfection. In patients with coronary artery disease or even with idiopathic dilated cardiomyopathy and hypertrophic cardiomyopathy, late contrast enhancement is associated with poor prognosis (1113). Randomized studies in these patient groups, we believe that the guidelines may gain specific recommendations in the relevant patient groups.

CMRI is useful for diagnosis of myocarditis or Tako-tsubo cardiomyopathy, which should be in differential diagnosis for patients with positive troponin level and normal coronaries. However, CMRI of our patient was evaluated at normal ranges and no specific diagnosis could be obtained. The patient had a mild increase in Troponin $\mathrm{T}$ $(0.152 \mathrm{ng} / \mathrm{mL})$ and the evaluation of the CMRI at normal ranges was attributed to the fact that the CMRI could not demonstrate a minimal myocardial injury at this level. The role of routine CMRI should be investigated in patients with elevated troponin levels with normal coronary arteries.

In our study, ARVC was clarified in one of the patients with suspected ARVC who had right ventricular ventricular arrhythmias. The ability to detect an increased risk of malignant arrhythmia in the presence of scarring in ARVC and cardiomyopathies provides an advantage to CMRI in clinical cardiac electrophysiology. We think that the risk assessment of patients with ventricular arrhythmias with CMRI should be used more widely in our country. There are several limitations of CMRI in our country. The lack of appropriate software, lack of adequate training and experience, inconsistencies between cardiology and radiology departments, and longer duration of acquisition time than other regions reduce the spread of CMRI. As authors, we believe that the widespread use of CMRI in cardiology practice is due to the fact that almost one-third of patients change their clinical approach.

\section{CONCLUSION}

CMRI is a very sensitive method of showing myocardial pathologies. The results of our study support the belief that CMRI should be performed more frequently with its ability of changing clinical management in one third of patients.

\section{Conflict of interests: None.}

\section{REFERENCES}

1. von Knobelsdorff-Brenkenhoff F, Bublak A, El-Mahmoud S, Wassmuth R, Opitz C, SchulzMenger J. Single-centre survey of the application of cardiovascular magnetic resonance in clinical routine. Eur Heart $\mathrm{J}$ Cardiovasc Imaging. 2013;14:62-8.

2. Bruder O, Wagner A, Lombardi M, Schwitter $\mathrm{J}$, van Rossum A, Pilz G, et al. European Cardiovascular Magnetic Resonance (EuroCMR) registry-multi national results from 57 centers in 15 countries. J Cardiovasc Magn Reson. 2013;15:9.

3. Friedrich MG. There is more than shape and function. J Am Coll Cardiol. 2008;52:1581-3.

4. von Knobelsdorff-Brenkenhoff F, SchulzMenger J. Role of cardiovascular magnetic resonance in the guidelines of the European Society of Cardiology. J Cardiovasc Magn Reson. 2016 Jan 22;18:6. doi: 10.1186/s12968-016-0225-6.

5. Yalin K, Golcuk E. Frequent Premature Ventricular Contractions and Cardiomyopathy, Chicken and Egg situation. J Atrial Fibrillation 2017, Epub of print

6. McMurray JJ, Adamopoulos S, Anker SD, Auricchio A, Bohm M, Dickstein K, et al. ESC Guidelines for the diagnosis and treatment of acute 
and chronic heart failure 2012: The Task Force for the Diagnosis and Treatment of Acute and Chronic Heart Failure 2012 of the European Society of Cardiology. Developed in collaboration with the Heart Failure Association(HFA) of the ESC. Eur Heart J. 2012;33:1787-847.

7. Authors/Task Force M, Adler Y, Charron P, Imazio M, Badano L, Baron-Esquivias G, et al. 2015 ESC Guidelines for the diagnosis and management of pericardial diseases: The Task Force for the Diagnosis and Management of Pericardial Diseases of the European Society of Cardiology (ESC)Endorsed by: The European Association for Cardio-Thoracic Surgery (EACTS). Eur Heart J. 2015;36:2921-64.

8. Authors/Task Force M, Roffi M, Patrono C, Collet JP, Mueller C, Valgimigli M et al. 2015 ESC Guidelines for the management of acute coronary syndromes in patients presenting without persistent ST-segment elevation: Task Force for the Management of Acute Coronary Syndromes in Patients Presenting without Persistent ST-Segment Elevation of the European Society of Cardiology (ESC). Eur Heart J. 2015 pii: ehv320. [Epub ahead of print].

9. Task Force on the management of STseamiotESoC, Steg PG, James SK, Atar D, Badano LP, Blomstrom-Lundqvist C, et al. ESC Guidelines for the management of acute myocardial infarction in patients presenting with ST- segment elevation. Eur Heart J. 2012;33:2569-619.

10. Erbel R, Aboyans V, Boileau C, Bossone E, Bartolomeo RD, Eggebrecht H, et al. 2014 ESC Guidelines on the diagnosis and treatment of aortic diseases: Document covering acute and chronic aortic diseases of the thoracic and abdominal aorta of the adult. The Task Force for the Diagnosis and Treatment of Aortic Diseases of the European Society of Cardiology (ESC). Eur Heart J. 2014;35:2873-926.

11. Golcuk E, Yalin K, Aksu T, Tiryakioglu SK, Bilge AK, Adalet K. Peri-Infarction Zone as a Risk Marker for Patients With Postmyocardial Infarction. Am J Med Sci. 2016;351:452-8

12. Perazzolo Marra M, De Lazzari M, Zorzi A, Migliore F, Zilio F, Calore C, Vettor G, Tona F1,
Tarantini G, Cacciavillani L, Corbetti F, Giorgi B, Miotto D, Thiene G, Basso C, Iliceto S, Corrado D. Impact of the presence and amount of myocardial fibrosis by cardiac magnetic resonance on arrhythmic outcome and sudden cardiac death in nonischemic dilated cardiomyopathy. Heart Rhythm. 2014;11:856-63

13. Suk T, Edwards C, Hart H, Christiansen JP. Myocardial scar detected by contrast-enhanced cardiac magnetic resonance imaging is associated with ventricular tachycardia in hypertrophic cardiomyopathy patients. Heart Lung Circ. 2008; $17: 370-4$ 